\title{
Article \\ The Effect of Listing Period on Corporate Social Responsibility: Evidence from Korea
}

\author{
Nam Chul Jung ${ }^{1}$ and Hyun Ah Kim ${ }^{2, *}$ \\ 1 School of Business Administration, Hongik University, 94 Wausan-ro, Mapo-gu, Seoul 04066, Korea; \\ jnc1208@hongik.ac.kr \\ 2 School of Industrial Management, Korea University of Technology \& Education, 1600 Chungjeol-ro, \\ Byeongcheon-myeon, Dongnam-gu, Cheonan City 31253, Korea \\ * Correspondence: kukolo@koreatech.ac.kr
}

Received: 5 April 2019; Accepted: 23 April 2019; Published: 25 April 2019

check for updates

\begin{abstract}
Newly listed firms can actively engage in corporate social responsibility (CSR) to build reputation, but they may postpone CSR until they have enough slack for it. Related to this, prior literature does not provide consistent results, the US evidence supports the latter while the Chinese results support the former. To extend the literature, we use Korean listed companies and examine the association between the listing period and CSR. We further investigate the effect of analyst following on the relationship. The empirical results show that firms with a shorter listing period invest more in CSR and that the association exists only in firm-years followed by analysts, indicating the importance of the information environment to inform CSR. We additionally find that young listed companies mainly use social contribution and soundness, which can be discretionarily conducted from a short-term perspective. The results of this study using CSR to obtain a short-term objective suggest that policymakers need to analyze a firm's behavior from various perspectives and to establish proper guidelines to achieve a long-term goal of CSR "sustainability".
\end{abstract}

Keywords: corporate social responsibility (CSR), listing period; analyst following; firm age; firm value

\section{Introduction}

This study examines whether the listing period is associated with corporate social responsibility (CSR). Specifically, we focus on the possibility that firms with a shorter listing period invest more in CSR activities to build a good reputation in Korea. Prior research suggests two competing hypotheses regarding the association between a company's age and CSR [1]. First, the resource-based theory ("outcome hypothesis") predicts that CSR increases with firm maturity. It claims that older firms are likely to invest more in CSR activities because they have slack based on their stable and predictable performance while younger companies cannot afford to invest in CSR due to continuous investment for their growth. The opposing hypothesis ("substitution hypothesis") expects a negative relationship between CSR and firm age. It argues that mature firms have less incentive to invest in CSR than young ones because they have already gained reputational capital.

Withisuphakorn and Jiraporn [1] use the US sample and report that older firms tend to invest more in CSR-related activities, supporting the resource-based theory. However, Yao et al. [2] found a negative relationship between corporate age and CSR disclosure in China, indicating different results depending on countries. Considering that national institutional contexts affect CSR, extensive research across countries is necessary to reach a consensus. Korean CSR is known as focusing on short-term outcomes rather than sustainability and mainly uses charitable social contribution, such as donations [3]. In addition, newly listed companies are less visible than existing public ones. Thus, they have a strong incentive to build reputation for their growth and CSR activities help them to form 
a good reputation $[4,5]$. Furthermore, Korea's hasty culture can encourage young companies after initial public offering (IPO) to conduct CSR for short-term value increases. Based on this possibility, we investigate whether the listing period affects CSR. We further examine whether financial analysts as an informational intermediary affect the relationship. Analysts are considered to be an important external monitoring mechanism in the literature. Prior studies provide evidence that the analyst coverage contributes to firm value by making firms more visible [6,7]. Therefore, analyst following is expected to play a role in delivering CSR activities of newly listed firms. Thus, the listing period is predicted to have a positive association with CSR activities when firms with the short-listing period are followed by analysts.

This study differs from previous studies in identifying a situation where firms use CSR activities from a short-term perspective. Because CSR is ultimately desirable to pursue for long-term growth, it is important to understand which factors motivate firms to use CSR activities in the short term. In this regard, our study suggests the possibility that the combination of the country characteristics and the reputation building incentive can induce firms to do short-term CSR activities.

Using Korean listed firms from 2011 to 2016, we found that firms with a shorter listing period are likely to invest more in CSR and the association exists only in companies followed by analysts. The results using sub-CSR score showed that recently listed firms are significantly related to soundness and social contribution, contributing to firm value. Taken together, our findings suggest that firms with relatively short listing period engage in CSR to enhance firm value under an environment where their CSR activities are widely delivered by financial analysts. Given that firms choose to go public for capital-raising at lower costs through a public stock exchange market, we interpret our results such that companies with low visibility use CSR to increase their reputation for smooth financing.

This study has several contributions to the literature. First, our study extends the literature by providing evidence that the relationship between corporate age and CSR can vary depending on the CSR characteristics of each country. In particular, our findings emphasize the importance of the information environment in CSR activities of less visible companies and show that firms strategically use CSR considering its contribution to firm value. Therefore, future researchers should conduct CSR studies from various perspectives. Second, this study has policy implications for regulators in emerging markets with similar CSR characteristics. The results of newly listed companies using CSR for short-term performance indicate that they may hinder the achievement of the CSR's long-term goal of "sustainability". Thus, nations with these CSR characteristics need to consider this when establishing CSR policies.

The remainder of the paper is organized as follows. Section 2 discusses previous studies and develops the hypotheses. Sections 3 and 4 explain the research method and empirical results, respectively. Finally, Section 5 presents the summary and conclusion.

\section{Literature Review and Hypothesis Development}

\subsection{Prior Research on Corporate Age and CSR}

Previous studies report various economic impacts of CSR, such as higher performance or better financial reporting quality [5], but the effect of corporate age on CSR has recently begun to draw attention. Withisuphakorn and Jiraporn [1] initially examined whether older firms are associated with greater investment in CSR based on the competing hypotheses, the outcome hypothesis (positive relationship), and the substitution hypothesis (negative association), and found evidence supporting the outcome hypothesis. They also showed that the firm age positively relates to all CSR categories, but mature companies invest more in diversity and environmental awareness. Consistent with this, Hasan and Habib [8] provided evidence that mature firms are associated with more CSR investments in their investigation of the relationship between firm life cycle and CSR.

Unlike the above research analyzing the US companies, Yao et al. [2] reported that younger Chinese firms are likely to disclose CSR, indicating their stronger desire for the capital market. Similarly, 
Lee and Choi [9] used Korean samples and found that firms at the growth stage invest more in CSR. These contrasting evidences show that the relationship between corporate age and CSR is inconsistent and unclear.

\subsection{Hypothesis Development}

Firms with potential growth opportunities generally decide to go public for capital raising to expand their operations [10]. Although not exactly matched, IPO companies are relatively young and likely to be in the growth stage [10]. Corporate managers can conduct CSR activities based on stakeholder theory or possible positive effects. The former requires them to be socially responsible for their stakeholders, and the latter differentiates them in terms of operating efficiency or employee quality that help maximize firm value $[5,11,12]$. The resource-based theory argues that substantial resource base and capabilities are necessary to obtain comparative advantages [13]. Therefore, firms with a shorter listing period, which are expected to mostly consist of growth firms, are less likely to engage in CSR activities because they invest a lot of money to produce differentiated product $[1,8,14]$.

CSR is an integral part of sustainability, but the understanding of CSR is not the same in the US and Korea which have different values and governance systems [15]. Specifically, Kim et al. [3] qualitatively analyzed Korean CSR and reported that it is for short-term outcomes despite Confucian values pursuing long-term growth. They argue that governmental pressures related to chaebols reform and Korea's hasty culture contribute to the short-term focus of CSR. The followings show how Korea understands CSR:

One of the major characteristics of Korean CSR is social contribution activities. Korean companies have been very actively engaged in social contribution as many of them have equated CSR with social contribution for a long time. They consider donations, contributions, voluntary services, etc. as the essence of CSR. (Hankyoreh Economic Research Institute) [16] (p. 27)

In Korea, corporate social responsibility (CSR) has become a popular concept with businesses. But they forget the most important elements of human rights and labor rights, highlighting only the "charity" parts, such as donations or blood-giving. ("Focus on Donations and Contribution Neglecting Human Rights and Labor Rights", The Kyunghyang Shinmun, 2 May 2013) [17]

Given that social contribution activities are accompanied by expense recognition and cash outflows, if they do not help increase corporate value, there is no reason for Korean companies to focus on such activities. The empirical evidence presented by Chung et al. [18] showed that they have a significantly positive association with firm value, explaining why Korean firms invest more in social contribution activities. Unlike other CSR activities, such as fairness, consumer protection, environment management, or employee satisfaction, social contributions are made in the short-term. Thus, they can be cut depending on situations [3]. This trait of Korean CSR may enable companies with a short listing period to engage in CSR activities to enhance firm value. Lee and Choi [9] increased this possibility by showing that in Korea, growth firms are likely to invest more in CSR than those in other life-cycle stages. In addition, CSR plays an important role in broadening a firm's shareholder base by attracting more institutional investors and increases stock liquidity [19]. Thus, we expect companies to be associated with CSR when they have a shorter listing period and low reputation in Korea. We state our first hypothesis as follows:

Hypothesis 1. Firms with a shorter listing period have a positive association with CSR activities.

Prior studies report that analysts are important as an external monitoring mechanism and an informational intermediary. Specifically, Chun and Shin [6] investigated whether analyst coverage is associated with CSR performance and found a positive relationship between the two. They interpreted their findings as the result of higher visibility derived by more analysts' reports, emphasizing their role as an informational intermediary. From the perspective of an external monitor, Yu [20] showed that 
companies are less likely to manage earnings when they are followed by more analysts. Furthermore, Jo and Harjoto [7] provided evidence that analyst following strengthens the relationship between CSR and firm value.

Analyst following is likely to increase CSR activities of newly listed firms because it can serve as a good channel for informing CSR activities to investors. In addition, considering the general positive association between CSR and firm value, analysts as a corporate monitor can induce managers to do CSR [20-22]. Thus, the first hypothesis is predicted to be supported only if companies with a shorter listing period are followed by financial analysts. We state our second hypothesis as follows:

Hypothesis 2. Firms with a shorter listing period have a positive association with CSR activities when they are followed by analysts.

\section{Research Design}

\subsection{CSR Performance}

Following prior studies, we used the Korea Economic Justice Institute (KEJI) index as a proxy for CSR performance $[9,23]$. The KEJI index is widely acknowledged by professionals and civic groups as an appropriate proxy for CSR activities in Korea. After several improvements in assessment methodology, since 2010, it has been calculated over public firms considering the following six items (total 100 points), soundness ( 25 points), fairness ( 20 points), social contribution (15 points), consumer protection (15 points), environmental management (10 points), and employee satisfaction (15 points).

The calculation procedure of the KEJI index is as follows.

(1) Calculate the actual value of the given indicator according to the formula

(2) Convert the actual value to a 100-point scale using the interpolation method

(Rating value $=$ min value $+\{($ max-value - min value $) \times($ actual value - actual min value $)\} /($ actual max value - actual min value)

(3) Calculate the final score considering the indicators' weight

Soundness evaluates corporate governance (11 points), investment (6 points), and corporate financing (8 points), such as activities of outside directors, ownership structure, R\&D expenditure, or debt guarantees for affiliates. Fairness consists of fairness (14 points) and transparency (6 points). The former examines economic concentration, partner relationships and the latter investigates the sincerity of disclosure and business reporting. Social contribution evaluates employment equality (7 points) and social contribution activity (6 points), and contribution to nation ( 2 points). Among various indicators, donation (4 points) is a key factor. Consumer protection consists of protection of consumer rights ( 7 points), observance of consumer law (5 points), and consumer safety ( 3 points) showing the firm's investment and interest in consumers. Environmental management is about environment improvement efforts (5 points). such as environmental protection program, environmental friendliness ( 2 points), and observance of environmental regulations ( 3 points). Finally, employee satisfaction consists of workplace health and safety (3.5 points), human resource development (2 points), salary and benefit ( 2.5 points), and labor-management relationship (7 points).

To ensure the homogeneity of CSR scores, the target year of our study commences in 2011.

\subsection{Empirical Model}

To test the association between the listing period and CSR performance, we use the following regression model based on Lee and Choi [9]:

$$
\begin{gathered}
C S R_{i t}=\alpha_{0}+\alpha_{1} L P(L N L P)_{i t}+\alpha_{2} \operatorname{SIZE}_{i t}+\alpha_{3} L E V_{i t}+\alpha_{4} R O A_{i t}+\alpha_{5} B I G 4_{i t}+\alpha_{6} F O R_{i t}+\alpha_{7} L A R_{i t} \\
+\alpha_{8} T A+\alpha_{9} R E_{i t}+\text { Year Dummy }+ \text { Industry Dummy }+\varepsilon_{i t}
\end{gathered}
$$


where:

CSR = CSR score provided by the KEJI;

$L P=$ post-listing period measured as the number of days from the IPO to the financial year-end date divided by 365 ;

$L N L P=$ the natural logarithm of the listing period;

SIZE = the natural logarithm of total assets;

$L E V=$ total debts divided by total assets;

$R O A=$ net income scaled by beginning total assets;

$B I G 4=1$ if the company appoints a Big 4 auditor and 0 otherwise;

$F O R=$ foreign investors' ownership;

$L A R=$ the largest shareholders' ownership;

$T A=$ total accruals scaled by beginning total assets;

$R E=$ retained earnings scaled by beginning total assets.

Prior studies generally measure corporate age from the earliest year included in the Center for Research in Security Prices (CRSP) database. Therefore, the definition of firm age is similar to the listing period in this study. Thus, we use listing period and firm age interchangeably in this study. In the above equation, $L P(L N L P)$ indicates the post-listing period measured as the number of years after the IPO (the natural logarithm of $L P$ ) following Pástor and Pietro [24]. If firms with shorter listing period invest more in CSR activities, we expect $\alpha_{1}$ to be significantly negative in the Equation (1). To test $\mathrm{H} 2$ regarding the effect of the information environment on the association between the listing period and CSR activities, we divided the sample into two depending on analyst following. Including the interaction term between the listing period and analyst following in Equation (1) increases the variance inflator factor (VIF) above 10, indicating a concern for multi-collinearity. Therefore, we split the sample into two subsamples: sample with and without analyst following. Consistent with our prediction, if analyst following plays an important role in informing CSR activities, the significance of $\alpha_{1}$ will be observed only in the sub-sample with analyst following.

Following the literature, we additionally controlled factors influencing CSR activities [1,9]. SIZE, measured by the natural logarithm of total assets, reflects visibility, resource access, and scale of operations, which is positively related to slack resources [25]. We predicted that larger firms participate in more CSR activities. Considering that better access to finance increases CSR [26], we expected the association between firms' leverage (LEV) and CSR to be negative. To control for the effect of firm performance and BIG4 auditor on CSR [27,28], we included ROA and BIG4 in Equation (1), respectively. The total accruals (TA) were included in the model based on the previous finding that the financial reporting quality would affect CSR activities [29,30]. We also included foreign investors' ownership $(F O R)$ and the largest shareholders' ownership $(L A R)$ as proxies for corporate governance and information demand level [31]. Retained earnings $(R E)$ was added to control for the effect of the corporate life cycle on CSR [8]. Finally, we included the industry (industry dummy) and year fixed effect (year dummy).

\subsection{Sample Selection}

We used Korean public companies from 2011 to 2016. Our target year starts in 2011 because in Korea, International Financial Reporting Standards (IFRS) were adopted in that year. We obtained firm-level financial information from DataGuide 5 of FnGuide, a comprehensive financial dataset in Korea. Panel A of Table 1 provides a sample selection process. Among 2225 firm-year observations, we excluded firm-years belonging to financial industries (145) and with insufficient data for the variable construction (284). Firm-years in financial industries were excluded because they have different characteristics in terms of operation, financial structure, and sanctions of regulatory authorities. In addition, their CSR scores are not comparable to those of non-financial industries because some indicators are based on elements specific to financial industries, such as compliance with financial regulations. As a result, our final sample consists of 1850 firm-year observations. Panel B of Table 1 
presents our sample distribution by year and the existence of analyst following. Firm-years followed by analysts account for about 45 percent of the sample. As shown in Panel C of Table 1, about 86 percent of our samples are distributed in Manufacturing (73\%), Wholesale and Retail (9\%), Publication, Media, Broadcasting, and Information Services (4\%).

Table 1. Sample selection procedure and distribution.

\begin{tabular}{|c|c|c|c|c|}
\hline \multicolumn{5}{|c|}{ Panel A: Sample Selection Criteria } \\
\hline Summary of Sample Selection Procedure & \multicolumn{4}{|c|}{ \# of Firms } \\
\hline Sample CSR score data available & \multicolumn{4}{|c|}{2225} \\
\hline Less: observations in financial industries & \multicolumn{4}{|c|}{-145} \\
\hline Less: observations with missing other control variables & \multicolumn{4}{|c|}{-230} \\
\hline Final Sample & \multicolumn{4}{|c|}{1850} \\
\hline \multicolumn{5}{|c|}{ Panel B: By Year and the Presence of Analyst Following } \\
\hline \multirow{2}{*}{ \# of Firms } & \multicolumn{2}{|c|}{ Without Analyst } & \multicolumn{2}{|c|}{ With Analyst } \\
\hline & $\mathbf{N}$ & $\%$ & $\mathbf{N}$ & $\%$ \\
\hline 2011 & 153 & 62.96 & 90 & 37.04 \\
\hline 2012 & 161 & 49.24 & 166 & 50.76 \\
\hline 2013 & 160 & 50 & 160 & 50 \\
\hline 2014 & 179 & 51.59 & 168 & 48.41 \\
\hline 2015 & 172 & 59.72 & 116 & 40.28 \\
\hline 2016 & 199 & 61.23 & 126 & 38.77 \\
\hline Total & 1024 & 55.35 & 826 & 44.65 \\
\hline \multicolumn{5}{|c|}{ Panel C: By Industry } \\
\hline Industry & \multicolumn{2}{|c|}{ \# of Firms } & \multicolumn{2}{|c|}{$\%$} \\
\hline Construction & \multicolumn{2}{|c|}{52} & \multicolumn{2}{|c|}{2.81} \\
\hline Educational Services & \multicolumn{2}{|c|}{8} & \multicolumn{2}{|c|}{0.43} \\
\hline Wholesale and Retail & \multicolumn{2}{|c|}{161} & \multicolumn{2}{|c|}{8.7} \\
\hline Facilities and Business Supporting & \multicolumn{2}{|c|}{15} & \multicolumn{2}{|c|}{0.81} \\
\hline Food \& Accommodations & \multicolumn{2}{|c|}{4} & \multicolumn{2}{|c|}{0.22} \\
\hline Art, Sports, and Leisure-related Services & \multicolumn{2}{|c|}{9} & \multicolumn{2}{|c|}{0.49} \\
\hline Transportation & \multicolumn{2}{|c|}{70} & \multicolumn{2}{|c|}{3.78} \\
\hline Electricity, Gas and Water Supply & \multicolumn{2}{|c|}{37} & \multicolumn{2}{|c|}{2} \\
\hline Technical Services & & & & \\
\hline Manufacturing Business & & & & \\
\hline Publication, Media, Broadcasting and Information Services & & & & \\
\hline Sewage and Others & & & & \\
\hline Total & & & & \\
\hline
\end{tabular}

\section{Empirical Results}

\subsection{Descriptive Statistics and Correlations}

Table 2 reports descriptive statistics of the variables used in our study. The mean (median) of CSR performance is 62.035 (62.027). The average listing period $(L P)$ is about 20.943 years, with minimum and maximum periods of 1.288 and 42.597 , respectively. The average value of the debt-to-asset ratio $(L E V)$ and return on assets $(R O A)$ are about $39.4 \%$ and $4.9 \%$, respectively. Approximately $67.7 \%$ of our sample appoint BIG4 as their auditors. The average ownership held by foreign investors (FOR) and the largest shareholders $(L A R)$ are about $9.6 \%$ and $45.1 \%$, respectively. About $44.6 \%$ of the firm-years are followed by analysts. The mean and standard deviation of Tobin's (TQ) are 1.152 and 0.678 , respectively. All continuous variables are winsorized at the upper and lower $1 \%$ level of distribution. 
Table 2. Descriptive statistics.

\begin{tabular}{ccccccccc}
\hline Variables & $\mathbf{N}$ & Mean & std. & MIN & $\mathbf{2 5 \%}$ & Median & $\mathbf{7 5 \%}$ & MAX \\
\hline CSR & 1850 & 62.035 & 2.995 & 54.862 & 59.954 & 62.027 & 64.111 & 69.225 \\
-Sound & 1850 & 16.507 & 1.766 & 12.370 & 15.309 & 16.519 & 17.722 & 20.785 \\
-Fair & 1850 & 15.323 & 1.426 & 11.450 & 14.850 & 15.350 & 16.850 & 17.150 \\
-Contri & 1850 & 5.986 & 1.329 & 3.750 & 4.668 & 6.306 & 7.087 & 8.585 \\
-Consum & 1850 & 6.000 & 1.947 & 4.550 & 4.550 & 5.150 & 6.150 & 10.550 \\
-Enviro & 1850 & 9.011 & 1.868 & 4.550 & 9.050 & 9.650 & 10.250 & 10.600 \\
-Employ & 1850 & 9.204 & 1.078 & 6.622 & 8.482 & 9.233 & 9.983 & 11.265 \\
LP & 1850 & 20.943 & 12.305 & 1.288 & 10.025 & 21.195 & 28.493 & 42.597 \\
LNLP & 1850 & 2.777 & 0.845 & 0.253 & 2.305 & 3.054 & 3.350 & 3.752 \\
SIZE & 1850 & 19.754 & 1.284 & 17.415 & 18.904 & 19.575 & 20.379 & 23.510 \\
LEV & 1850 & 0.394 & 0.180 & 0.063 & 0.249 & 0.388 & 0.538 & 0.814 \\
ROA & 1850 & 0.049 & 0.048 & -0.054 & 0.019 & 0.041 & 0.069 & 0.211 \\
BIG4 & 1850 & 0.677 & 0.468 & 0.000 & 0.000 & 1.000 & 1.000 & 1.000 \\
FOR & 1850 & 0.096 & 0.124 & 0.000 & 0.011 & 0.041 & 0.137 & 0.527 \\
LAR & 1850 & 0.451 & 0.158 & 0.112 & 0.334 & 0.461 & 0.560 & 0.796 \\
TA & 1850 & -0.017 & 0.065 & -0.181 & -0.050 & -0.019 & 0.011 & 0.190 \\
RE & 1850 & 0.412 & 0.269 & -0.249 & 0.237 & 0.427 & 0.600 & 0.916 \\
FOL & 1850 & 0.446 & 0.497 & 0.000 & 0.000 & 0.000 & 1.000 & 1.000 \\
TQ & 1850 & 1.152 & 0.678 & 0.489 & 0.782 & 0.973 & 1.263 & 4.433 \\
\hline
\end{tabular}

Notes: Appendix A presents variable definitions. All continuous variables are winsorized at $1 \%$ and $99 \%$ levels.

In Table 3, we divided the sample into three groups based on the listing period, SHORT, MIDDLE, and $L O N G$, and compared the means of CSR performance across groups. As shown in Table 3, the mean value decreases as the listing period increases and the differences between two groups (SHORT vs. MIDDLE, MIDDLE vs. LONG) are significant at the $10 \%$ level. Unlike other specific CSR items, social contribution (Contri) and employee satisfaction (Employ) show a relatively consistent trend even if the direction is contrary in Figure 1. However, the significance between groups only exists in Contri in Table 3, indicating that the overall CSR performance is mainly based on social contribution and preliminary supporting the negative association between the listing period and CSR performance.

Table 3. Comparison of corporate social responsibility (CSR) performance across three groups.

\begin{tabular}{|c|c|c|c|c|c|}
\hline \multirow{2}{*}{ Variables } & \multicolumn{3}{|c|}{ CSR Performance by Group } & \multicolumn{2}{|c|}{ Mean Difference (t-value) } \\
\hline & Short & Middle & Long & Middle-Short & Long-Middle \\
\hline CSR & 62.190 & 62.110 & 61.804 & $1.88^{*}$ & $1.79 *$ \\
\hline -Sound & 16.585 & 16.664 & 16.273 & -0.79 & $3.88^{* * *}$ \\
\hline -Fair & 15.370 & 15.191 & 15.408 & $2.19 * *$ & $-2.62 * * *$ \\
\hline -Contri & 6.157 & 6.004 & 5.794 & $1.99 * *$ & $2.84^{* * *}$ \\
\hline -Consum & 6.015 & 6.214 & 5.771 & $-1.73^{*}$ & $4.01^{* * *}$ \\
\hline -Enviro & 8.925 & 8.835 & 9.274 & 0.80 & $-4.19^{* * *}$ \\
\hline -Employ & 9.136 & 9.209 & 9.268 & -1.18 & -0.97 \\
\hline
\end{tabular}

Table 4 reports the Pearson correlations of the variables. LP and LNLP are negatively and significantly correlated with CSR. CSR shows a positive relationship to SIZE, ROA, BIG4, FOR, RE, $F O L$, and $T Q$ at the $1 \%$ level. In contrast, CSR is negatively associated with $L E V, L A R$, and $T A$ at the $1 \%$ level. $L P$ is negatively related to $R O A, B I G 4, L A R, F O R$, and TQ. Meanwhile, firm-years followed by analysts have a positive correlation with CSR, SIZE, ROA, BIG4, FOR, and RE. 


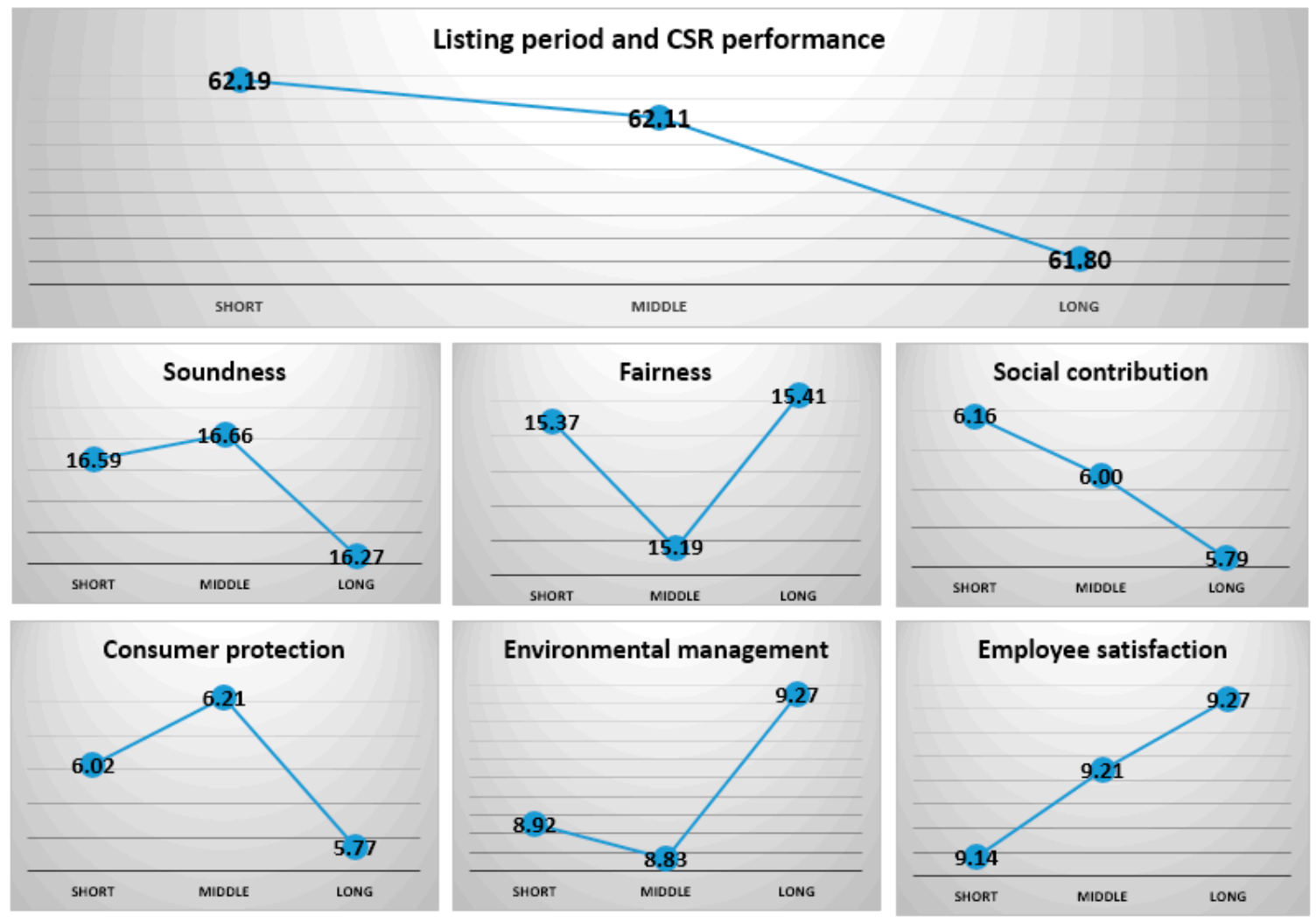

Figure 1. This figure presents the relationship between the listing period and corporate social responsibility (CSR) scores (sub-CSR scores) across three groups (SHORT, MIDDLE, and LONG). The figure numbers are in Table 3.

Table 4. Pearson correlations matrix.

\begin{tabular}{|c|c|c|c|c|c|c|c|c|c|c|c|c|}
\hline Variables & CSR & LP & LNLP & SIZE & LEV & ROA & BIG4 & FOR & LAR & TA & RE & FOL \\
\hline \multirow{2}{*}{ LP } & -0.053 & & & & & & & & & & & \\
\hline & 0.022 & & & & & & & & & & & \\
\hline \multirow{2}{*}{ LNLP } & -0.029 & 0.919 & & & & & & & & & & \\
\hline & 0.028 & 0.000 & & & & & & & & & & \\
\hline \multirow{2}{*}{ SIZE } & 0.168 & 0.033 & 0.005 & & & & & & & & & \\
\hline & 0.000 & 0.154 & 0.846 & & & & & & & & & \\
\hline \multirow{2}{*}{ LEV } & -0.114 & -0.010 & -0.020 & 0.218 & & & & & & & & \\
\hline & 0.000 & 0.659 & 0.383 & 0.000 & & & & & & & & \\
\hline \multirow{2}{*}{ ROA } & 0.218 & -0.168 & -0.167 & 0.018 & -0.284 & & & & & & & \\
\hline & 0.000 & 0.000 & 0.000 & 0.446 & 0.000 & & & & & & & \\
\hline \multirow{2}{*}{ BIG4 } & 0.084 & -0.092 & -0.095 & 0.410 & 0.079 & 0.022 & & & & & & \\
\hline & 0.000 & 0.000 & 0.000 & 0.000 & 0.001 & 0.350 & & & & & & \\
\hline \multirow{2}{*}{ FOR } & 0.247 & -0.027 & -0.026 & 0.495 & -0.154 & 0.270 & 0.231 & & & & & \\
\hline & 0.000 & 0.252 & 0.268 & 0.000 & 0.000 & 0.000 & 0.000 & & & & & \\
\hline \multirow{2}{*}{ LAR } & -0.303 & -0.079 & -0.097 & -0.074 & -0.077 & -0.013 & 0.016 & -0.223 & & & & \\
\hline & 0.000 & 0.001 & 0.000 & 0.002 & 0.001 & 0.572 & 0.493 & 0.000 & & & & \\
\hline \multirow{2}{*}{ TA } & -0.006 & 0.007 & -0.009 & -0.070 & -0.015 & 0.210 & -0.027 & -0.071 & 0.001 & & & \\
\hline & 0.810 & 0.764 & 0.700 & 0.003 & 0.519 & 0.000 & 0.253 & 0.002 & 0.983 & & & \\
\hline \multirow{2}{*}{$\mathrm{RE}$} & 0.165 & 0.028 & 0.061 & 0.100 & -0.606 & 0.349 & 0.090 & 0.239 & 0.123 & 0.030 & & \\
\hline & 0.000 & 0.228 & 0.009 & 0.000 & 0.000 & 0.000 & 0.000 & 0.000 & 0.000 & 0.198 & & \\
\hline \multirow[b]{2}{*}{ FOL } & 0.174 & -0.213 & -0.219 & 0.399 & 0.008 & 0.190 & 0.262 & 0.263 & -0.033 & -0.039 & 0.159 & \\
\hline & 0.000 & 0.000 & 0.000 & 0.000 & 0.724 & 0.000 & 0.000 & 0.000 & 0.160 & 0.095 & 0.000 & \\
\hline \multirow{2}{*}{ TQ } & 0.190 & -0.141 & -0.141 & 0.086 & 0.003 & 0.386 & 0.065 & 0.306 & -0.181 & 0.005 & -0.045 & 0.204 \\
\hline & 0.000 & 0.000 & 0.000 & 0.000 & 0.886 & 0.000 & 0.005 & 0.000 & 0.000 & 0.841 & 0.051 & 0.000 \\
\hline
\end{tabular}

Notes: Appendix A presents variable definitions; $p$-values are below correlation coefficients. 


\subsection{The Association between the Listing Period and CSR Activities (Hypothesis 1)}

Table 5 provides the empirical results of Hypothesis 1 . We report robust $t$-statistics adjusted for firm-level clustering, following Petersen [32].

Table 5. Listing period and CSR.

\begin{tabular}{|c|c|c|c|c|c|}
\hline \multirow{3}{*}{ Variables } & \multirow{3}{*}{ Predicted Sign } & \multicolumn{4}{|c|}{ Dependent Variables: $C S R$} \\
\hline & & \multicolumn{2}{|c|}{ (1) LP } & \multicolumn{2}{|c|}{ (2) LNLP } \\
\hline & & Coefficient & $t$-statistics & Coefficient & $t$-statistics \\
\hline Intercept & $+/-$ & $58.267^{* * *}$ & 32.33 & $58.708^{* * *}$ & 31.82 \\
\hline LP & - & $-0.022 * * *$ & -2.85 & & \\
\hline LNLP & - & & & $-0.249 * *$ & -2.19 \\
\hline SIZE & + & $0.284^{* * *}$ & 3.13 & $0.270^{* * *}$ & 2.96 \\
\hline LEV & - & -0.944 & -1.56 & -0.876 & -1.44 \\
\hline $\mathrm{ROA}$ & + & $8.796^{* * *}$ & 5.27 & $9.022^{* * *}$ & 5.37 \\
\hline BIG4 & + & 0.155 & 0.83 & 0.169 & 0.90 \\
\hline FOR & + & 1.251 & 1.35 & 1.289 & 1.38 \\
\hline LAR & - & $-5.967^{* * *}$ & -10.83 & $-5.953 * * *$ & -10.70 \\
\hline TA & - & -1.381 & -1.37 & -1.477 & -1.45 \\
\hline RE & + & $0.750 * *$ & 2.06 & $0.785^{* *}$ & 2.12 \\
\hline Year Dummy & & \multicolumn{2}{|c|}{ Included } & \multicolumn{2}{|c|}{ Included } \\
\hline Industry Dummy & & \multicolumn{2}{|c|}{ Included } & \multicolumn{2}{|c|}{ Included } \\
\hline Adj. $R^{2}$ & & \multicolumn{2}{|c|}{0.277} & \multicolumn{2}{|c|}{0.274} \\
\hline F-statistics & & \multicolumn{2}{|c|}{$25.88^{* * *}$} & \multicolumn{2}{|c|}{$25.50 * * *$} \\
\hline $\mathrm{N}$ & & \multicolumn{2}{|c|}{1850} & \multicolumn{2}{|c|}{1850} \\
\hline Clustering & & \multicolumn{2}{|c|}{ Firm } & \multicolumn{2}{|c|}{ Firm } \\
\hline Max VIF & & \multicolumn{2}{|c|}{2.06} & \multicolumn{2}{|c|}{2.05} \\
\hline
\end{tabular}

Notes: Appendix A presents variable definitions; $t$-statistics are corrected at the firm level. ${ }^{* * *}, * *, *$ indicate significance at $1 \%, 5 \%$, and $10 \%$ levels (two-tailed), respectively.

In Table 5, the adjusted $R^{2}$ value (0.274-0.277), F-statistics (25.50-25.88), and low variance inflator factor (VIF) (2.05-2.06) indicate the goodness of fit of our model. Consistent with Hypothesis 1, we found a significantly negative association between $L P$ and CSR (coefficient $=-0.022 ; t$-statistics value $=-2.85$ ) and the result is maintained when we use $L N L P$ instead of $L P$ (coefficient $=-0.249$; $t$-statistics value $=-2.19$ ). Unlike the previous US evidence [1,8], our results support the substitution hypothesis of younger firms' desire for the reputation capital through CSR activities and suggest that firms with a shorter listing period invest more in CSR in Korea. This indicates that Korean firms in the early stage of listing actively promote them through CSR activities, especially social contribution as shown in Table 3 and Figure 1. The economic effect of the listing period is about $13.2 \%$ decreased in CSR when it increases from 1st quarter to 3rd quarter. Our estimation is the coefficient on LP $\times$ (3rd quarter listing period -1 st quarter listing period)/(the SD of the CSR), specifically, $-0.022 \times(28-$ 10)/2.995 $=-0.132$.

The coefficients of the control variables are generally consistent with our predictions. CSR shows a positive relationship with SIZE, ROA, and RE while it is negatively associated with $L A R$. On the other hand, $L E V, B I G 4, F O R$, and TA shows the expected sign with CSR, but there is no statistical significance.

\subsection{The Effect of Analyst Following on the Association between the Listing Period and CSR Activities (Hypothesis 2)}

Table 6 presents the results regarding Hypothesis 2 and Panel A and B show the results when independent variables are $L P$ and $L N L P$, respectively. Regardless of independent variables, we found that the significant association of Table 5 remains only in the subsample with analyst following. Specifically, the coefficient on $L P(L N L P)$ is $-0.032(-0.294)$ and significant at $1 \%(10 \%)$ level in Panel A 
(Panel B). The results are consistent with Hypothesis 2, indicating that firms with a short listing period strongly engage in CSR activities under the situation where their CSR is widely informed by financial analysts and the effect of CSR is expected to be greater [20,22]. Meanwhile, the coefficients of control variables are generally consistent with our expectation.

Table 6. The effect of analyst following on the association between listing period and CSR.

\begin{tabular}{|c|c|c|c|c|c|}
\hline \multicolumn{6}{|c|}{ Panel A: Independent Variables-LP } \\
\hline \multirow{3}{*}{ Variables } & \multirow{3}{*}{ Predicted Sign } & \multicolumn{4}{|c|}{ Dependent Variables: $C S R$} \\
\hline & & \multicolumn{2}{|c|}{ Without Analyst Following } & \multicolumn{2}{|c|}{ With Analyst Following } \\
\hline & & Coefficient & $t$-statistics & Coefficient & $t$-statistics \\
\hline Intercept & $+/-$ & $56.014 * * *$ & 23.56 & $64.401 * * *$ & 24.37 \\
\hline LP & - & -0.008 & -0.84 & $-0.032 * * *$ & -2.77 \\
\hline SIZE & + & $0.367^{* * *}$ & 2.91 & 0.072 & 0.57 \\
\hline LEV & - & -0.601 & -0.88 & $-2.56^{* *}$ & -2.15 \\
\hline $\mathrm{ROA}$ & + & $8.001^{* * *}$ & 3.79 & $8.437^{* * *}$ & 2.88 \\
\hline BIG4 & + & 0.027 & 0.11 & 0.376 & 1.33 \\
\hline FOR & + & 1.01 & 0.84 & 1.624 & 1.32 \\
\hline LAR & - & $-5.579 * * *$ & -8.24 & $-6.942 * * *$ & -8.3 \\
\hline TA & - & -0.715 & -0.53 & -1.465 & -0.88 \\
\hline $\mathrm{RE}$ & + & 0.609 & 1.55 & -0.092 & -0.11 \\
\hline Year Dummy & & \multicolumn{2}{|c|}{ Included } & \multicolumn{2}{|c|}{ Included } \\
\hline Industry Dummy & & \multicolumn{2}{|c|}{ Included } & \multicolumn{2}{|c|}{ Included } \\
\hline Adj. $R^{2}$ & & \multicolumn{2}{|c|}{0.267} & \multicolumn{2}{|c|}{0.288} \\
\hline$F$-statistics & & \multicolumn{2}{|c|}{$15.19 * * *$} & \multicolumn{2}{|c|}{$11.93^{* * *}$} \\
\hline $\mathrm{N}$ & & \multicolumn{2}{|c|}{1024} & \multicolumn{2}{|c|}{826} \\
\hline \multicolumn{6}{|c|}{ Panel B: Independent Variables- $L N L P$} \\
\hline \multirow{3}{*}{ Variables } & \multirow{3}{*}{ Predicted Sign } & \multicolumn{4}{|c|}{ Dependent Variables: $C S R$} \\
\hline & & \multicolumn{2}{|c|}{ Without Analyst Following } & \multicolumn{2}{|c|}{ With Analyst Following } \\
\hline & & Coefficient & $t$-statistics & Coefficient & $t$-statistics \\
\hline Intercept & $+/-$ & $56.238^{* * *}$ & 23.42 & $64.814^{* * *}$ & 24.07 \\
\hline LNLP & - & -0.085 & -0.56 & $-0.294 *$ & -1.86 \\
\hline SIZE & + & $0.358^{* * *}$ & 2.85 & 0.052 & 0.41 \\
\hline LEV & - & -0.571 & -0.84 & $-2.447^{* *}$ & -2 \\
\hline ROA & + & $8.089^{* * * *}$ & 3.78 & $8.83^{* * *}$ & 3 \\
\hline BIG4 & + & 0.033 & 0.14 & 0.376 & 1.31 \\
\hline FOR & + & 1.044 & 0.87 & 1.612 & 1.3 \\
\hline LAR & - & $-5.583^{* * *}$ & -8.19 & $-6.809^{* * *}$ & -8.11 \\
\hline $\mathrm{TA}$ & - & -0.75 & -0.56 & -1.581 & -0.95 \\
\hline $\mathrm{RE}$ & + & 0.613 & 1.55 & -0.006 & -0.01 \\
\hline Year Dummy & & \multicolumn{2}{|c|}{ Included } & \multicolumn{2}{|c|}{ Included } \\
\hline Industry Dummy & & \multicolumn{2}{|c|}{ Included } & \multicolumn{2}{|c|}{ Included } \\
\hline Adj. $R^{2}$ & & \multicolumn{2}{|c|}{0.267} & & \\
\hline F-statistics & & & & & \\
\hline $\mathrm{N}$ & & & & & \\
\hline
\end{tabular}

Notes: Appendix A presents variable definitions; $t$-statistics are corrected at the firm level. ${ }^{* * *}, * *, *$ indicate significance at $1 \%, 5 \%$, and $10 \%$ levels (two-tailed), respectively.

\subsection{Additional Analyses}

\subsubsection{Listing Period and Sub-CSR Activities}

We additionally analyzed the association between the listing period and individual CSR activities. Lee and Choi [9] found that growth firms invest more in Sound and Contri in Korea. In addition, Chung et al. [18] provided evidence that Sound and Contri play an important role in increasing firm value in Korea. Considering these findings and the short-term focus of Korean CSR [3], our results are expected to remain in Sound and Contri. 
As shown in Table 7, we found that the negative association between $L P$ and CSR is observed only in Sound and Contri, consistent with our prediction. The finding of Table 7 has a policy implication because it is another evidence of the short-term focus of Korean CSR, deviating from the core objective of CSR, "sustainability".

Table 7. Additional analysis: using sub-CSR scores.

\begin{tabular}{|c|c|c|c|c|c|c|}
\hline \multirow{4}{*}{ Variables } & \multicolumn{6}{|c|}{ Dependent Variables: Sub-CSR scores } \\
\hline & (1) & (2) & (3) & (4) & (5) & (6) \\
\hline & Soundness & Fairness & $\begin{array}{c}\text { Social } \\
\text { Contribution }\end{array}$ & $\begin{array}{l}\text { Consumer } \\
\text { Protection }\end{array}$ & $\begin{array}{l}\text { Environment } \\
\text { Management }\end{array}$ & $\begin{array}{l}\text { Employee } \\
\text { Satisfaction }\end{array}$ \\
\hline & $\begin{array}{c}\text { Coefficient } \\
\text { (t-statistics) }\end{array}$ & $\begin{array}{c}\text { Coefficient } \\
\text { (t-statistics) }\end{array}$ & $\begin{array}{c}\text { Coefficient } \\
\text { ( } t \text {-statistics) }\end{array}$ & $\begin{array}{c}\text { Coefficient } \\
(t \text {-statistics) }\end{array}$ & $\begin{array}{c}\text { Coefficient } \\
(t \text {-statistics) }\end{array}$ & $\begin{array}{c}\text { Coefficient } \\
\text { ( } t \text {-statistics) }\end{array}$ \\
\hline Intercept & $\begin{array}{c}14.168^{* * *} \\
(16.77)\end{array}$ & $\begin{array}{c}22.481^{* * *} \\
(25.60)\end{array}$ & $\begin{array}{c}1.510 * * \\
(2.16)\end{array}$ & $\begin{array}{c}1.575^{* * *} \\
(4.30)\end{array}$ & $\begin{array}{c}9.965^{* * *} \\
(25.90)\end{array}$ & $\begin{array}{c}8.446^{* * *} \\
(13.53)\end{array}$ \\
\hline LP & $\begin{array}{c}-0.010 * * \\
(-2.31)\end{array}$ & $\begin{array}{l}-0.006 \\
(-1.60)\end{array}$ & $\begin{array}{c}-0.007 * * \\
(-2.22)\end{array}$ & $\begin{array}{l}-0.002 \\
(-1.47)\end{array}$ & $\begin{array}{c}0.000 \\
(-0.09)\end{array}$ & $\begin{array}{l}0.002 \\
(0.57)\end{array}$ \\
\hline SIZE & $\begin{array}{c}0.267^{* * *} \\
(6.32)\end{array}$ & $\begin{array}{c}-0.341^{* * *} \\
(-7.36)\end{array}$ & $\begin{array}{c}0.206^{* * *} \\
(5.51)\end{array}$ & $\begin{array}{c}0.184^{* * *} \\
(9.36)\end{array}$ & $\begin{array}{l}-0.006 \\
(-0.28)\end{array}$ & $\begin{array}{l}-0.021 \\
(-0.65)\end{array}$ \\
\hline LEV & $\begin{array}{c}-1.400^{* * *} \\
(-4.24)\end{array}$ & $\begin{array}{l}0.143 \\
(0.52)\end{array}$ & $\begin{array}{l}0.337 \\
(1.16)\end{array}$ & $\begin{array}{l}0.043 \\
(0.33)\end{array}$ & $\begin{array}{l}0.036 \\
(0.30)\end{array}$ & $\begin{array}{l}-0.077 \\
(-0.34)\end{array}$ \\
\hline ROA & $\begin{array}{c}1.788^{* *} \\
(1.99)\end{array}$ & $\begin{array}{l}0.227 \\
(0.34)\end{array}$ & $\begin{array}{c}5.180 * * * \\
(5.85)\end{array}$ & $\begin{array}{l}0.363 \\
(1.08)\end{array}$ & $\begin{array}{c}-0.714^{*} \\
(-1.93)\end{array}$ & $\begin{array}{c}1.867^{* * *} \\
(3.36)\end{array}$ \\
\hline BIG4 & $\begin{array}{c}0.200 * \\
(1.91)\end{array}$ & $\begin{array}{l}-0.093 \\
(-1.14)\end{array}$ & $\begin{array}{l}0.086 \\
(1.15)\end{array}$ & $\begin{array}{l}-0.040 \\
(-0.97)\end{array}$ & $\begin{array}{l}-0.019 \\
(-0.55)\end{array}$ & $\begin{array}{l}0.008 \\
(0.11)\end{array}$ \\
\hline FOR & $\begin{array}{c}1.522 * * * \\
(3.77)\end{array}$ & $\begin{array}{l}-0.105 \\
(-0.26)\end{array}$ & $\begin{array}{l}0.176 \\
(0.48)\end{array}$ & $\begin{array}{c}0.551^{* * *} \\
(3.12)\end{array}$ & $\begin{array}{c}-0.361^{* *} \\
(-1.97)\end{array}$ & $\begin{array}{l}-0.412 \\
(-1.29)\end{array}$ \\
\hline LAR & $\begin{array}{c}-4.546^{* * *} \\
(-15.64)\end{array}$ & $\begin{array}{l}-0.400 \\
(-1.52)\end{array}$ & $\begin{array}{c}-0.374 * \\
(-1.66)\end{array}$ & $\begin{array}{c}-0.192 * \\
(-1.67)\end{array}$ & $\begin{array}{l}0.006 \\
(0.05)\end{array}$ & $\begin{array}{c}-0.400^{* *} \\
(-2.01)\end{array}$ \\
\hline TA & $\begin{array}{c}-1.153 * * \\
(-2.16)\end{array}$ & $\begin{array}{l}0.035 \\
(0.07)\end{array}$ & $\begin{array}{l}0.551 \\
(1.13)\end{array}$ & $\begin{array}{l}-0.170 \\
(-0.92)\end{array}$ & $\begin{array}{l}-0.008 \\
(-0.03)\end{array}$ & $\begin{array}{l}-0.712^{*} \\
(-1.92)\end{array}$ \\
\hline RE & $\begin{array}{c}0.333 * \\
(1.69)\end{array}$ & $\begin{array}{l}0.377^{* *} \\
(2.34)\end{array}$ & $\begin{array}{l}0.092 \\
(0.46)\end{array}$ & $\begin{array}{c}-0.156^{* *} \\
(-2.00)\end{array}$ & $\begin{array}{l}0.051 \\
(0.68)\end{array}$ & $\begin{array}{l}0.041 \\
(0.31)\end{array}$ \\
\hline $\begin{array}{c}\text { Year } \\
\text { Industry }\end{array}$ & $\begin{array}{l}\text { Included } \\
\text { Included }\end{array}$ & $\begin{array}{l}\text { Included } \\
\text { Included }\end{array}$ & $\begin{array}{l}\text { Included } \\
\text { Included }\end{array}$ & $\begin{array}{l}\text { Included } \\
\text { Included }\end{array}$ & $\begin{array}{l}\text { Included } \\
\text { Included }\end{array}$ & $\begin{array}{l}\text { Included } \\
\text { Included }\end{array}$ \\
\hline Adj. $R^{2}$ & 0.457 & 0.334 & 0.162 & 0.926 & 0.900 & 0.241 \\
\hline F-statistics & $57.01 * * *$ & $33.93 * * *$ & $13.06^{* * *}$ & $852.67^{* * *}$ & $611.17^{* * *}$ & $21.52 * * *$ \\
\hline $\mathrm{N}$ & 1850 & 1850 & 1850 & 1850 & 1850 & 1850 \\
\hline
\end{tabular}

Notes: Appendix A presents variable definitions; $t$-statistics are corrected at the firm level. ${ }^{* * *}, * *, *$ indicate significance at $1 \%, 5 \%$, and $10 \%$ levels (two-tailed), respectively.

\subsubsection{Sub-CSR Activities and Firm Value}

Chung et al. [18] found that Sound and Contri have a positive association with firm value, but their target years, from 2012 to 2015, are different from ours, from 2011 to 2016. Thus, the result may not be valid in our study. To confirm the previous finding, we used our sample and analyzed the relationship between individual CSR activities and corporate value, measured as Tobin's Q.

As shown in Table 8, we found the result consistent with the prior study, suggesting that investors still evaluate Sound and Contri positively among CSR activities. The findings of Table 8, supporting the contribution of two sub-CSR indices to firm value, enable us to provide a more precise explanation about the CSR activities of newly listed firms. Sound is related to corporate governance, investment, and corporate financing. Contri is closely associated with donations. It is relatively easy to change the two sub-CSRs unlike other sub-CSR indices, such as fairness, consumer protection, and employee satisfaction. Therefore, the results can be interpreted that firms with a short listing period understand the association between sub-CSR and firm value. Thus, they focus on Sound and Contri to increase their market value and to build reputation from a short-term perspective. Meanwhile, the un-tabulated result shows that the association between sub-CSR activities and corporate value does not differ depending on analyst following. 
Table 8. Additional analysis: (sub-)CSR scores and firm value.

\begin{tabular}{|c|c|c|c|c|c|c|c|}
\hline \multicolumn{8}{|c|}{$\begin{array}{l}T Q=\alpha_{0}+\alpha_{1} \text { CSR (Sound, Fair, Contri, Consum, Enviro, Employ) }+\alpha_{2} \text { SIZE }+\alpha_{3} L E V+\alpha_{4} B I G 4+\alpha_{5} R O A+ \\
\alpha_{6} F O R+\alpha_{7} L A R+\text { Year Dummy }+ \text { Industry Dummy }+\varepsilon\end{array}$} \\
\hline \multirow{4}{*}{ Variables } & \multicolumn{6}{|c|}{ Dependent Variables: $T Q$} & \multirow[b]{2}{*}{ (7) } \\
\hline & (1) & (2) & (3) & (4) & (5) & (6) & \\
\hline & CSR & Soundness & Fairness & $\begin{array}{c}\text { Social } \\
\text { Contribution }\end{array}$ & $\begin{array}{l}\text { Consumer } \\
\text { Protection }\end{array}$ & $\begin{array}{l}\text { Environment } \\
\text { Management }\end{array}$ & $\begin{array}{l}\text { Employee } \\
\text { Satisfaction }\end{array}$ \\
\hline & $\begin{array}{l}\text { Coefficient } \\
(t \text {-statistics) }\end{array}$ & $\begin{array}{l}\text { Coefficient } \\
(t \text {-statistics })\end{array}$ & $\begin{array}{l}\text { Coefficient } \\
(t \text {-statistics) }\end{array}$ & $\begin{array}{c}\text { Coefficient } \\
(t \text {-statistics) }\end{array}$ & $\begin{array}{l}\text { Coefficient } \\
(t \text {-statistics })\end{array}$ & $\begin{array}{l}\text { Coefficient } \\
(t \text {-statistics) }\end{array}$ & $\begin{array}{l}\text { Coefficient } \\
\text { ( } t \text {-statistics) }\end{array}$ \\
\hline Intercept & $\begin{array}{l}-0.375 \\
(-0.61)\end{array}$ & $\begin{array}{l}0.484 \\
(0.96)\end{array}$ & $\begin{array}{l}0.785 \\
(1.34)\end{array}$ & $\begin{array}{c}0.994^{* *} \\
(2.10)\end{array}$ & $\begin{array}{c}1.103^{* *} \\
(2.40)\end{array}$ & $\begin{array}{c}1.639^{* * *} \\
(3.29)\end{array}$ & $\begin{array}{l}0.807 \\
(1.60)\end{array}$ \\
\hline CSR & $\begin{array}{c}0.025^{* * *} \\
(3.98)\end{array}$ & & & & & & \\
\hline -Sound & & $\begin{array}{c}0.042^{* * *} \\
(3.23)\end{array}$ & & & & & \\
\hline -FAIR & & & $\begin{array}{l}0.013 \\
(0.88)\end{array}$ & & & & \\
\hline -Contri & & & & $\begin{array}{c}0.051^{* * *} \\
(4.11)\end{array}$ & & & \\
\hline -Consum & & & & & $\begin{array}{l}-0.023 \\
(-0.65)\end{array}$ & & \\
\hline -Enviro & & & & & & $\begin{array}{c}-0.057^{*} \\
(-1.91)\end{array}$ & \\
\hline -Employ & & & & & & & $\begin{array}{l}0.031 \\
(1.60)\end{array}$ \\
\hline SIZE & $\begin{array}{l}-0.045 \\
(-1.62)\end{array}$ & $\begin{array}{c}-0.049 * \\
(-1.77)\end{array}$ & $\begin{array}{l}-0.033 \\
(-1.17)\end{array}$ & $\begin{array}{c}-0.048 * \\
(-1.75)\end{array}$ & $\begin{array}{l}-0.033 \\
(-1.11)\end{array}$ & $\begin{array}{l}-0.038 \\
(-1.35)\end{array}$ & $\begin{array}{l}-0.037 \\
(-1.33)\end{array}$ \\
\hline LEV & $\begin{array}{c}0.701 \text { *** } \\
(4.24)\end{array}$ & $\begin{array}{c}0.733 \text { *** } \\
(4.51)\end{array}$ & $\begin{array}{c}0.666^{* * *} \\
(4.02)\end{array}$ & $\begin{array}{c}0.648^{* * *} \\
(3.96)\end{array}$ & $\begin{array}{c}0.668^{* * *} \\
(4.07)\end{array}$ & $\begin{array}{c}0.663^{* * *} \\
(4.02)\end{array}$ & $\begin{array}{c}0.668^{* * *} \\
(4.05)\end{array}$ \\
\hline BIG4 & $\begin{array}{l}0.044 \\
(0.97)\end{array}$ & $\begin{array}{l}0.040 \\
(0.88)\end{array}$ & $\begin{array}{l}0.050 \\
(1.10)\end{array}$ & $\begin{array}{l}0.044 \\
(0.98)\end{array}$ & $\begin{array}{l}0.049 \\
(1.06)\end{array}$ & $\begin{array}{l}0.049 \\
(1.07)\end{array}$ & $\begin{array}{l}0.049 \\
(1.08)\end{array}$ \\
\hline ROA & $\begin{array}{c}4.813^{* * *} \\
(5.91)\end{array}$ & $\begin{array}{c}4.973^{* * *} \\
(6.05)\end{array}$ & $\begin{array}{c}5.052 * * * \\
(6.12)\end{array}$ & $\begin{array}{c}4.767 * * * \\
(5.79)\end{array}$ & $\begin{array}{c}5.069 * * * \\
(6.10)\end{array}$ & $\begin{array}{c}5.025 * * * \\
(6.09)\end{array}$ & $\begin{array}{c}5.014 * * * \\
(6.00)\end{array}$ \\
\hline FOR & $\begin{array}{c}1.119^{* * *} \\
(2.78)\end{array}$ & $\begin{array}{c}1.086^{* * *} \\
(2.67)\end{array}$ & $\begin{array}{c}1.155^{* * *} \\
(2.86)\end{array}$ & $\begin{array}{c}1.145^{* * *} \\
(2.83)\end{array}$ & $\begin{array}{c}1.167^{* * *} \\
(2.92)\end{array}$ & $\begin{array}{c}1.133^{* * *} \\
(2.78)\end{array}$ & $\begin{array}{c}1.166^{* * *} \\
(2.89)\end{array}$ \\
\hline LAR & $\begin{array}{c}-0.286 * \\
(-1.75)\end{array}$ & $\begin{array}{l}-0.243 \\
(-1.44)\end{array}$ & $\begin{array}{c}-0.423 * * * \\
(-2.61)\end{array}$ & $\begin{array}{c}-0.411^{* * *} \\
(-2.53)\end{array}$ & $\begin{array}{c}-0.431 * * * \\
(-2.62)\end{array}$ & $\begin{array}{c}-0.426^{* * *} \\
(-2.63)\end{array}$ & $\begin{array}{c}-0.415^{* * *} \\
(-2.57)\end{array}$ \\
\hline Year & Included & Included & Included & Included & Included & Included & Included \\
\hline Industry & Included & Included & Included & Included & Included & Included & Included \\
\hline Adj. $R^{2}$ & 0.299 & 0.297 & 0.291 & 0.299 & 0.291 & 0.293 & 0.292 \\
\hline F-statistics & $30.03 * * *$ & $29.69 * * *$ & $28.84^{* * *}$ & $29.98^{* * *}$ & $28.81^{* * *}$ & $29.12 * * *$ & $29.03 * * *$ \\
\hline $\mathrm{N}$ & 1850 & 1850 & 1850 & 1850 & 1850 & 1850 & 1850 \\
\hline
\end{tabular}

Notes: Appendix A presents variable definitions; $t$-statistics are corrected at the firm level. ${ }^{* * *},{ }^{* *},{ }^{*}$ indicate significance at $1 \%, 5 \%$, and $10 \%$ levels (two-tailed), respectively.

\subsubsection{Additional Analysis of Listing Period Divided by Decile}

For the robustness of our results, we used the decile variable, measured as dividing the listing period into 10 groups and re-examined the main analysis. Un-tabulated results are qualitatively similar to our main findings.

\section{Conclusions}

Firms in the early stage of listing can actively engage in CSR to build reputation, but they may postpone CSR until they are mature enough to create stable and predictable performance and to have slack for it [1]. In this study, we investigated the relationship between the listing period and CSR using Korean listed firms. Considering the short-term focus of Korean CSR [3], we hypothesized that firms with a shorter listing period invest more in CSR and analyst following as an information environment affects the association. The empirical results supported our hypotheses, indicating that firms with a short listing period use CSR to promote them and financial analysts play an important 
role in informing CSR. Further, sub-CSR results showed that recently listed companies are related to soundness and social contribution, contributing to firm value.

This study extends the literature by showing that the relationship between corporate age and CSR is different from that of the US and that analyst following helps less visible companies to inform their CSR. In particular, the results of newly listed firms focusing on social contribution, such as donations, are consistent that Korean CSR is mainly related to short-term outcome. Therefore, policymakers need to think about various ways to change the direction to the CSR's long-term goal "sustainability".

Our findings are expected to provide a base for future research regarding the association between the listing period and CSR activities as follows. The results can be interpreted that firms have little interest in CSR as their listing period becomes longer. To achieve the society-wide goal of CSR, it is essential to induce mature firms to invest in CSR activities. Therefore, in-depth research is needed from various perspectives on why these companies do not engage in CSR activities. In addition, this study investigated the effect of analysts, but other monitoring mechanisms or information intermediaries, such as credit rating agencies, can influence the association. Thus, related future research can help understand the CSR behavior of firms with a short listing period. Finally, $R^{2}$ is very different depending on individual sub-CSR in Table 7. This provides the possibility that the determinants of each sub-CSR are not the same. Therefore, in future research, it would be of interest to identify the factors which affect sub-CSRs separately.

Author Contributions: H.A.K. developed a conceptual research plan and carried out the literature review. N.C.J. participated in the design of the study and performed statistical analysis. H.A.K. and N.C.J. drafted the manuscript. H.A.K. and N.C.J. read and approved the final manuscript.

Funding: This research received no external funding.

Conflicts of Interest: The authors declare no conflict of interest.

\section{Appendix A}

Table A1. Variable definitions.

\begin{tabular}{|c|c|}
\hline Variable & Definition \\
\hline CSR & CSR score provided by the KEJI \\
\hline -Sound & $\begin{array}{l}\text { Soundness score provided by the KEJI based on soundness of corporate governance (i.e., ownership } \\
\text { structure), investment (i.e., R\&D expenditure), and corporate financing (i.e., debt guarantees for affiliates) }\end{array}$ \\
\hline -Fair & $\begin{array}{l}\text { Fairness score provided by the KEJI based on fairness (i.e., economic concentration, partner relationships), } \\
\text { and transparency (i.e., the sincerity of disclosure and business reporting) }\end{array}$ \\
\hline -Contri & $\begin{array}{l}\text { Social contribution score provided by the KEJI based on employment equality (i.e., share of female } \\
\text { workers), social donations, and tax payment) }\end{array}$ \\
\hline -Consum & $\begin{array}{l}\text { Consumer protection score provided by the KEJI based on protection of consumer rights (i.e., consumer } \\
\text { satisfaction certification), observance of consumer law, and consumer safety }\end{array}$ \\
\hline -Enviro & $\begin{array}{l}\text { Environmental management score provided by the KEJI based on environmental improvement efforts } \\
\text { (i.e., environmental investment), environmental friendliness, and violation and contamination }\end{array}$ \\
\hline -Employ & $\begin{array}{l}\text { Employee satisfaction score provided by the KEJI based on workplace health and safety (i.e., industrial } \\
\text { accidents), human capital development, and wages and benefits }\end{array}$ \\
\hline LP & The period from the date of listing to measurement year-end date divided by year \\
\hline LNLP & The natural logarithm of the listing period \\
\hline SIZE & The natural logarithm of total assets \\
\hline LEV & Total debts divided by total assets \\
\hline ROA & Net income scaled by beginning total assets \\
\hline BIG4 & 1 if the company appoints a Big 4 auditor and 0 otherwise \\
\hline FOR & Foreign investors' ownership \\
\hline LAR & The largest shareholders' ownership \\
\hline TA & Total accruals scaled by beginning total assets \\
\hline RE & Retained earnings scaled by beginning total assets \\
\hline FOL & 1 if an analyst report exists, 0 otherwise \\
\hline TQ & Tobin's Q; the sum of the market value of shares and book value of debt divided by the book value of assets. \\
\hline
\end{tabular}




\section{References}

1. Withisuphakorn, P.; Jiraporn, P. The effect of firm maturity on corporate social responsibility (CSR): Do older firms invest more in CSR? Appl. Econ. Lett. 2016, 23, 298-301. [CrossRef]

2. Yao, S.; Wang, J.; Song, L. Determinants of Social Responsibility Disclosure by Chinese Firms. The University of Nottingham-China Policy Institute. Discussion Paper, 2011. Available online: https://www.coursehero.com/file/ 17406115/DETERMINANTS-OF-SOCIAL-RESPONSIBILITY-DISCLOSURE-BY-CHINESE-FIRMS/ (accessed on 25 April 2019).

3. Kim, C.H.; Amaeshi, K.; Harris, S.; Suh, C.J. CSR and the national institutional context: The case of South Korea. J. Bus. Res. 2013, 66, 2581-2591. [CrossRef]

4. Kim, W.; Weisbach, M. Do Firms Go Public to Raise Capital? Available online: https://www.nber.org/papers/ w11197 (accessed on 25 April 2019).

5. Malik, M. Value-enhancing capabilities of CSR: A brief review of contemporary literature. J. Bus. Ethics 2015, 127, 419-438. [CrossRef]

6. Chun, H.M.; Shin, S.Y. Does analyst coverage enhance firms' corporate social performance? Evidence from Korea. Sustainability 2018, 10, 2561. [CrossRef]

7. Jo, H.; Harjoto, M.A. Corporate governance and firm value: The impact of corporate social responsibility. J. Bus. Ethics 2011, 103, 351-383. [CrossRef]

8. Hasan, M.M.; Habib, A. Corporate life cycle, organizational financial resources and corporate social responsibility. J. Contemp. Account. Econ. 2017, 13, 20-36. [CrossRef]

9. Lee, W.J.; Choi, S.U. Effects of corporate life cycle on corporate social responsibility: Evidence from Korea. Sustainability 2018, 10, 3794. [CrossRef]

10. Chang, S.J. Venture capital financing, strategic alliances, and the initial public offerings of Internet startups. J. Bus. Ventur. 2004, 19, 721-741. [CrossRef]

11. Clarkson, P.M.; Fang, X.; Li, Y.; Richardson, G. The relevance of environmental disclosures: are such disclosures incrementally informative? J. Account. Public Policy 2013, 32, 410-431. [CrossRef]

12. Servaes, H.; Tamayo, A. The impact of corporate social responsibility on firm value: The role of customer awareness. Manag. Sci. 2013, 59, 1045-1061. [CrossRef]

13. Campbell, J.L. Why would corporations behave in socially responsible ways? An institutional theory of corporate social responsibility. Acad. Manag. Rev. 2007, 32, 946-967. [CrossRef]

14. Hay, R.D.; Ginter, P. Strategies for maintaining a share of the market. In Proceedings of the Annual Meeting of the Southern Academy of Management, Atlanta, GA, USA, 1979.

15. Miles, L. The application of Anglo-American corporate practices in societies influenced by Confucian values. Bus. Soc. Rev. 2006, 111, 305-321. [CrossRef]

16. HERI (Hankyoreh Economic Research Institute). [AFF] S.Korea maintains 5 companies in 'East Asia 30'. Available online: http://english.hani.co.kr/arti/english_edition/e_business/502532.html. (accessed on 21 January 2019).

17. The Kyunghyang Shinmun. Available online: http://english.khan.co.kr/khan_art_view.html?artid= 201305021856237\&code $=710100$ (accessed on 21 January 2019).

18. Chung, C.; Jung, S.; Young, J. Do CSR activities increase firm value? Evidence from the Korean market. Sustainability 2018, 10, 3164. [CrossRef]

19. Kim, J.B.; Li, B.; Liu, Z. Does social performance influence breadth of ownership? J. Bus. Financ. Account. 2018, 45, 1164-1194. [CrossRef]

20. Yu, F.F. Analyst coverage and earnings management. J. Financ. Econ. 2008, 88, 245-271. [CrossRef]

21. Margolis, J.D.; Walsh, J.P. Misery loves companies: Rethinking social initiatives by business. Adm. Sci. Q. 2003, 48, 268-305. [CrossRef]

22. Knyazeva, D. Corporate Governance, Analyst Following, and Firm Behavior; University of Rochester: Rochester, NY, USA, 2007; unpublished.

23. Jeong, K.H.; Jeong, S.W.; Lee, W.J.; Bae, S.H. Permanency of CSR Activities and Firm Value. J. Bus. Ethics 2018, 152, 207-223. [CrossRef]

24. Pástor, L.; Pietro, V. Stock valuation and learning about profitability. J. Financ. 2003, 58, 1749-1789. [CrossRef]

25. Lepoutre, J.; Heene, A. Investigating the impact of firm size on small business social responsibility: A critical review. J. Bus. Ethics 2006, 67, 257-273. [CrossRef] 
26. Cheng, B.; Ioannou, I.; Serafeim, G. Corporate social responsibility and access to finance. Strateg. Manag. J. 2014, 35, 1-23. [CrossRef]

27. Waddock, S.A.; Graves, S.B. The corporate social performance-financial performance link. Strateg. Manag. J. 1997, 18, 303-319. [CrossRef]

28. Sun, W.C.; Huang, H.W.; Dao, M.; Young, C.S. Auditor selection and corporate social responsibility. J. Bus. Financ. Account. 2017, 44, 1241-1275. [CrossRef]

29. Andersen, M.L.; Hong, Y.D.; Olsen, L. Accruals quality and corporate social responsibility: The role of industry. J. Account. Financ. 2012, 12, 65-79.

30. Kim, Y.; Park, M.S.; Wier, B. Is earnings quality associated with corporate social responsibility? Account. Rev. 2012, 87, 761-796. [CrossRef]

31. Oh, W.Y.; Chang, Y.K.; Martynov, A. The effect of ownership structure on corporate social responsibility: Empirical evidence from Korea. J. Bus. Ethics 2011, 104, 283-297. [CrossRef]

32. Petersen, M.A. Estimating standard errors in finance panel data sets: comparing approaches. Rev. Financ. Stud. 2009, 22, 435-480. [CrossRef]

(C) 2019 by the authors. Licensee MDPI, Basel, Switzerland. This article is an open access article distributed under the terms and conditions of the Creative Commons Attribution (CC BY) license (http://creativecommons.org/licenses/by/4.0/). 